the organ wandering abuut is proof that its pedicle is long; and when there is a long pedicle, it is not improbable that in course of time the tumor may beeome so rotated on its axis as to affect its blood-supply very seriously, or eren to arrest it altogether. It is well known that this oeeurs in some cases of ovarian tumors, and aeeounts for the development of acute symptoms of a very urgent character. It is in these eases that immediate uperation becomes necessary to save life. Ordinarily in cases of wandering spleen uo operation is performed unless it prorluces some eonstitutional disturbance.

In view of the eomparative simplicity and safety of an early operation, and of the otber faet, that this wandering spleen, from twisting of its pediele, may quickly place the patient's life in peril, would it not be in the interest of the patient to advise early exeision? This is the recognized practice in all orarian tumors, and the ehange from the old plan of waiting till some constitutional disturbance arose, necounts in some derree for the small mortality in ovnriotomy in comparison with the results obtained twenty years ngo. Now every operator, as soon as his dingnosis is made, proceeds to remore the tumor; he linds no adhesions, aud almost every ease recorers. This patient, with nothing but $n$ small indurated mass in the left umbilical region, is in better bealth than she was with her wandering spleen. From the fact that many perzons regain excellent bealth after the excision of the spleen, it is clear that the organ is not essential to life. From this point of view, therefure, there is no reason why it should not be treated the same as a cystie orary.

The recovery of this patient from so grave a condition, and in the manner related, is witlout parallel in the annals of surgery. The attempt at removal was not made. On making the exploratory incision, the state of matters disclosed left no doubt that the patient would die on the table if cxeisiou were procecded with; but nature resened the patient by using the tract of the incision ns $\mathbf{n}$ ehannel by which to eliminate the pus and broken down fragments of the gangrenous spleen from the system.

\title{
CURE OF THE FALSETTO VOICE.'
}

BY J. C. MúnaLL, A.JY., M.D., I.R.C.E.I.,

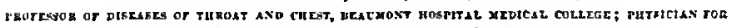

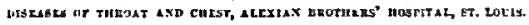

At puberty, roice in the man, as every one knows, undergoes a renarkable change. Its timbre and intensity may remain the same, but its pitch beeones much lowered; the puerile becomes masculine.

1 Iend before the American Laryugological Society, September, I 858. 
In some this change occurs quite suddenly, in more the transformation is gradual, but in a very few, though puherty he fully established, the roice renains unaltered, or, more usually, its pitch hecomes ligherreaches the falsetto; the boy is man in everytling hut his voice.

Very frequently this condition undergoes spontaneous cure. At a period of uncertain length after puherty-it may be months, it may he years-the lad in some vocal effort, hitherto untried, finds that the roice of a nian issues froin lis ehest. He repeats the experiment, and the heretofore unused, or misused, muscles which control the lower register, having once felt the stimulus of aetion, automatienlly respond to future exigencies.

More rarely-indeed, this condition is quite a rare one-this falsetto voice persists beyond the second into the third deende when social and husiness interests hegin to eluster ahout the man, nnd his condition is made a very humilinting one.

Until recently I wns under the jmpression that every laryngologist was familiar with this anomaly and its enre, hut the history related me by my last pntient, of various attempts made in this direetion, convineed me that I need not apologize for the introduction of the subjeet at this meeting, further fortified by the faet that, within my knowledge. the theme has received hut little attention in literature.

MIr. S. G. F., hanker's elerk, aged twenty-five, until within sixteen months a resident of Washington, $\mathfrak{D}$. C., hut for the period mentioned an inhahitant of St. Louis, consulted me with regard to an infirmity of the voice in Novernber, 1887. His statement, made in quite a high falsetto bey, revenled the fact that he had never yet talked in any other manner, with the followiag exception: He had occasionally rendered monosyllahic initations of lis brother's deep basso voice, but had been warned to avoid this, for fear of injury to the rocal apparatus.' He hal never yet uttered a complete sentence in other than bis present squeaking, puerile roice. He felt sure that his voice was of ligher piteh than previous to puherty.

There existed a partial, not a literal, exception to this latter assertion. Direet questioning elieited the inportant and instructive faet that, in laughing, the voice was of low piteh, as in other men. He had quite given up hope of relief, inasmuch as a specialist of repute at his own home, having unsuccessfully treated him during severnl montlis, had then called in consultation a veteran and distinguished laryngologist from wnother eity, who could, however, suggest no other thempeutic measure than the one already chiefly employed, namely, elcetricity. He had further eonsulted another laryngologist in a large Eastern city without avail. He was told uniformly that the trouble was of paralytic anture, and given an unfavorahle prognosis.

Instrumental examination revealed a eondition, erudely spealing, of perfect health of the upper air-passages. He was in all other respects a normal individual, including his genital organs. It is matter of common knowledge tbat hoys who have been eastrated-the eunuehs of the East

1 Sature asserted iteelf; but wos promptly euppreseed. 
-maintilin their pucrile voices after the nge of puberty, and it lias been written that as late as in the last century choir hoys witl fine voices suffered castration that their higle tenor or falsct to voices might remin unclianged after puherty to serve in the choirs of cloistered orders of monks. The general pulblic, acquninted with these facts, is prone to cousider that a full-grown man with $n$ falsetto voice must he lacking in genital development. One of $\mathbf{m y}$ patients insisted on proving to ne that he was not defiejent in this respect. I ueed not say that the public is elltirely wrong in the suspicion.'

Observation with the larygozespe proved in the patient in question thint, fir from there being auy paretic condition present, the true and false cords during phonation npproximated uore closely than they should have done; an observation proven hy comparion in the same individual a few moments later, when his falsetto roice had given way to a normal baritone. It could then he readily seeu that the vocal clink was now much larger; that the whole larynx was lacking in the element of numscular tenseness which had cliaracterized the vocal attitude of the falsetto voice. The patient was told with an nir of conffdent nuthority, after carcful and prolonged laryngoscopic examination, that his vocal npparatus was in a condition of perfect licalth; that the error was purely physiological, and consisted in the fuulty use of his roice, and that he would leave the consulting roon curcd of his filsetto tous. This information was given in this coufident manner that it might carry conviction; thint it might stimulnte the nerre clcment involved to in correct performance of function.

The chin of tlic patient was now depressed on the stcrnum, this being done for its mental effect ruther thun to relns tension or depress the larynx; and whilst in this position I uttcred n low guttural, and asked the patient to imitate anc, which he nt once did. His attention was then drawn to the fact that he conld utter low tones. His hend being again depressed, he at once readily initated $m_{Y}$ low tones in counting. A conversation cnsued, his confidence was establishcd, and the cure alreost accomplished. The patient must, lowerer, be assured that his newly nequircd roice is proper to lime, for nt first be can scarcely believe that the unfamiliar tones form his normal roice.

In a word, the remedy consists in telling the patient that he has a normal voice, and, hy some device, proving it to him. For the first few days, unless the patient fixes his attention on each vocal effort, he is apt to commence a senteuce iu his former falset to bey.

Mrs pntient was, tlierefore, requested to remain at his lodgings for two davs to exexpe busiuess diversions, and coneentrate his ntteation on his voice; to pristise speaking nnd rending aloud. At the end of this time he found that, even when lis mind was direrted from his roice, that he spoke quite naturally. At the end of three months, on being requeted to speak in his forwer falsetto key, he found himelf utterly unable to do so.

\footnotetext{
1 The matter is embarrassing to the patient, who is conscious that the public suepect bin to be a cunucl.
} 
I have thus far had three ense, their history and cure being similar. In ny first ease, occurring fourtcen years ngo, I noticed that the indiridual spoke in falsetto tones, but lnughed in quite natural ones, and it was the clev to my succesful theory nnd treatment. It occurred to me that laughing was a natural aet, articulate speech an artificial one, the product of imitation and training. It therefore suggested itself to me that the artificial tone of speech could he trained to imitate the naturnl one of laughter.

'The muscles at physiological fault are undouhtedly the thyro-arytenoids, from the plyysiological fact that they are the internnl tensors of the laryns, and from the clinical fact that in un cases the ellipse betreen the cords during vocalization was much larger after restoration of the normal voice.

This helief is further strengthened by laryngoscopic ohservations in a totally opposite class of cases, to which also-indeed little, if any-attention hns heen made hy authors, namely, paralysis of the thyro-arytenoids in adults, caused by excessite tese of the high register before puberty.

I lave been eonsulted by two gentlemen for voice trouhles whose history was identieal. In both, direct questioning drew fortb the bistory that there bad been habitunlly exeessive use of the bigb register for two or thrce yenrs before puberty; in the one ease in singing, and in the otiter in elocution. At puberty botb found tbeir voiees changet, to becorae busky, very deep, rough, ineapable of maintaining so long a sentenee, without inspiring, as before puberty, so aptly termed phonative woste of breath, and both unable, witb any effort, to reach a note higber than the middle register of a baritone.

Their ages at the time of observation were, respeetively, twenty-seren and tbirty-tro. Their roices bad undergone no ehange from the one into which tliey passed at puberty. In both the roeal ellipse was rery large, the siekle sbape of the eords during phonation being well marked. There existed the well-known elinical pieture of paralysis of the thyroarytenoillei.

My purpose in mentioning tbis class of enses iz to offer the conelusion that if, in the onc, the suhjeetive and objective signs collectively be the cract :Intithesis of those in the other, and it be admitted tbat in the one paralysis of the thyro-ary tenoids be the exnct dingnosis, hyper-tension of the eanie muscles must be cbiefly concerned in the enission of the falsetto roice. 